\section{Partial edentulism and treatment options}

\section{Parsiyel dişsizlik ve tedavi seçenekleri}

\section{Assoc. Prof. Zeynep Özkurt-Kayahan \\ Yeditepe University, Faculty of Dentistry, Department of Prosthodontics, Istanbul}

\section{Assoc. Prof. Ceyda Özçakır Tomruk}

Yeditepe University, Faculty of Dentistry, Department of Oral and Maxillofacial Surgery, Istanbul

\section{Prof. Ender Kazazoğlu}

Yeditepe University, Faculty of Dentistry, Department of Prosthodontics, Istanbul

Received: 4 July 2016

Accepted: 8 October 2016

DOI: 10.5505/yeditepe.2017.62207

\section{Corresponding author:}

Assoc. Prof. Zeynep Özkurt-Kayahan

Yeditepe University, Faculty of Dentistry

Department of Prosthodontics, Bağdat cad. No: 238

34728, Goztepe, Istanbul, Turkey

Tel: 00905333269488

Fax: 00902163636211

Email: zeynepozkurt@hotmail.com

\section{SUMMARY}

Aim: The purpose of this study was to determine the prevalence of various types of partial edentulism, and type of prosthetic restorations most commonly chosen to treat the patients.

Materials and Methods: A retrospective evaluation was conducted in Department of Prosthodontics, Dental School of Yeditepe, Turkey, by examining the digital record system of the faculty. The patients were selected randomized and the inclusion criteria were; patients who had partial edentulism at least on their one jaw, who had panoramic radiographs, whose treatment had been finished, and who had no treatment. Age, gender, Kennedy classification and treatment options were recorded. Descriptive statistical methods and Chisquare test were used to analyze data. An alpha level of 0.05 was used for all statistical analyses.

Results: There were 345 patients (147 males, 198 females) with the mean age of $50.88 \pm 14.09$ years. Kennedy III was the most common in the maxilla $(71.1 \%)$ and in the mandible (55.9\%). Partial edentulism was most frequently managed by fixed partial dentures in the maxilla $(57.9 \%)$ and in the mandible $(41.7 \%)$. Implant treatment was applied to $13-14 \%$ of the patients.

Conclusions: Dental implants were the least common treatment option for partial edentulism. Fixed partial dentures were the most common treatment for Kennedy III and IV whereas removable partial dentures were the most common for Kennedy I and II.

Key words: Partial edentulism, classification, treatment option, prevalence, implant.

\section{ÖZET}

Amaç: Bu çalışmanın amacı, farklı kısmi dişsizlik tiplerinin belirlenmesi ve bu disssizliklerin protetik tedavi seçeneklerinin incelenmesidir.

Gereç ve Yöntem: Yeditepe Üniversitesi Dişhekimliği Fakültesi Protetik Diş Tedavisi Anabilim Dalı'nda, dijital kayıt sistemi incelenerek retrospektif bir değerlendirme yapıldı.

Hastalar kayıt sisteminden randomize olarak seçildi ve çalışmaya şu kriterlere göre dahil edildi; en az bir çenesinde kısmi dişsizliğe sahip olmak, panoramik radyografi çektirmiş olmak, protetik tedavisi tamamlanmış ya da tedavi yaptırmadan ayrılmış olmak. Hastaların yaşı, cinsiyeti, kısmi dişsizlik (Kennedy) sınıflaması ve tedavi seçenekleri kaydedildi. Elde edilen verilerin istatistiksel analizinde tanımlayıcı yöntemler ve Ki-Kare testi kullanıldı. Anlamlıık $p<0,05$ düzeyinde değerlendirildi.

Bulgular: Çalışmaya yaş ortalaması 50,88 $\pm 14,09$ olan 345 hasta (147 erkek, 198 kadın) dahil edildi. Kennedy III dişsizliğin, üst çenede $(\% 71,1)$ ve alt çenede $(\% 55,9)$ en sık görülen dişsizlik tipi olduğu belirlendi. Kısmi dişsizliğin üst çenede $(\% 57,9)$ ve alt çenede $(\% 41,7)$ sıklıkla sabit protezlerle tedavi edildiği gözlendi. Hastaların yalnızca \%13-14'üne im- 
plant tedavisi uygulandı.

Sonuç: Dental implantlar, kısmi dişsizlikte en az tercih edilen tedavi seçeneğiydi. Sabit protezler Kennedy III ve IV için en yaygın tedavi yöntemi iken, hareketli bölümlü protezler Kennedy I ve II için en yaygın tedavi seçeneğiydi.

Anahtar kelimeler: Kısmi dişsizlik, sınıflama, tedavi seçeneği, sıklık, implant.

\section{INTRODUCTION}

Tooth loss caused by recurrent caries, traumatic incidents, certain congenital anomalies, endodontic complications, or periodontal diseases may result in the reduced masticatory efficiency and esthetics. ${ }^{1}$ Prosthodontic rehabilitation is indicated to restore function, esthetics and phonetics, and to replace missing teeth. ${ }^{2}$ Among the prosthetic options for partial edentulism, missing teeth and supporting oral tissues are replaced with fixed partial dentures (FPDs), removable partial dentures (RPDs), overdentures, and implant prosthesis. ${ }^{3,4}$ Any tooth replacement should be performed by a detailed evaluation of the existing dental situation and functional condition of the patient. Besides, the risks, benefits and costs of the selected treatment modality should be discussed with the patients. ${ }^{5}$

There are many partial edentulism classification methods, however, Kennedy's classification is the most widely accepted method to classify the partially edentulous arches. ${ }^{6,7}$ There are four main types in Kennedy classification; Class I (bilateral edentulous areas located posterior to the remaining natural teeth), Class II (a unilateral edentulous area located posterior to the remaining natural teeth), Class III (a unilateral edentulous area with natural teeth remaining both anterior and posterior to it), and Class IV (a single bilateral edentulous area located anterior to the remaining natural teeth). ${ }^{8-10}$

The frequency of various classes of partial edentulism and restoration types may reflect the aspects of the population on dental health prioritizations. 6 Although several studies have been performed in different parts of the world on the prevalence of various classes of partial edentulism, classes of RPDs, and/or restoration types, 3,6,7,9,11-13 there are no data available on both frequency of Kennedy classification and their treatment options in a subpopulation in Turkey. Therefore, the aim of this study was (i) to investigate the prevalence of partial edentulism classes, and (ii) to identify the prosthetic treatment options, such as overdenture, removable partial denture, fixed partial denture, implant or no restoration, for patients attending the Yeditepe University Faculty of Dentistry, Istanbul, Turkey.

\section{MATERIALS AND METHODS}

This retrospective evaluation was conducted in a Turkish subpopulation, consisting of a sample of patients attending to Department of Prosthodontics, Faculty of Dentistry, Yeditepe University, Istanbul, Turkey from January 2008 to December 2010. The retrospective evaluation was performed by examining the digital record system of the faculty which involved all patient files. The labarotary record system of the prosthetic department was also evaluated. The patients were selected randomized and the inclusion criteria were; patients who had partial edentulism at least on their one jaw, who had panoramic radiographs, whose treatment had been finished, and who had no treatment. Age, gender, Kennedy classification, treatment options and treatment clinic type were recorded. Third molar teeth were not included to the classification. SPSS for Windows 15.0 (SPSS Inc., Chicago, IL, USA) was used for the statistical analysis. Descriptive statistical methods and Chi-square test were used to analyze data. An alpha level of 0.05 was used for all statistical analyses.

\section{RESULTS}

There were 345 patients (147 males, 198 females) with the mean age of $50.88 \pm 14.09$ years. The patients were treated in undergraduate student clinic $(38.8 \%)$, postgraduate student clinic (9\%) and specialist clinic (45.2\%). Seven percent of patients had no treatment. There were 690 jaws; 41 were edentuluos, 122 were fully dentate and 527 were partially edentulous. The most frequent type of partial edentulism was Kennedy III, in both the maxilla $(71.1 \%)$ and the mandible (55.8\%). Kennedy IV was the least prevalent type $(2.8 \%$ in the maxilla, $0.7 \%$ in the mandible) (Table 1).

Table 1: Distribution of Kennedy classification

\begin{tabular}{|l|c|c|c|c|c|}
\hline Arches & KI & KII & KIII & KIV & Total \\
\hline Maxilla & $25(10.1 \%)$ & $39(15.8 \%)$ & $175(71.1 \%)$ & $7(2.8 \%)$ & 246 \\
\hline Mandible & $66(23.4 \%)$ & $56(19.9 \%)$ & $157(55.8 \%)$ & $2(0.7 \%)$ & 281 \\
\hline Total & 91 & 95 & 332 & 9 & 527 \\
\hline
\end{tabular}

Table 2 shows the distribution of prosthetic treatment type according to Kennedy classification in maxilla. RPDs were more prevalant in Kennedy I and II patients (68\% and $51.3 \%$, respectively), while FPDs were more prevalant in Kennedy III and IV patients ( $76 \%$ and $57 \%$, respectively).

Table 2: Distribution of treatment type according to Kennedy classification in maxilla

\begin{tabular}{|l|c|c|c|c|c|}
\hline & FPD & RPD & Implant & No treatment & Total \\
\hline KI & 0 & $17(68 \%)$ & $58(20 \%)$ & $3(12 \%)$ & 25 \\
\hline KII & $6(15.4 \%)$ & $20(51.3 \%)$ & $10(25.6 \%)$ & $3(7.7 \%)$ & 39 \\
\hline KIII & $133(76 \%)$ & $6(3.4 \%)$ & $19(10.9 \%)$ & $17(9.7 \%)$ & 175 \\
\hline KIV & $4(57 \%)$ & $1(14.5 \%)$ & $2(28.5 \%)$ & 0 & 7 \\
\hline
\end{tabular}


Table 3 shows the distribution of prosthetic treatment type according to Kennedy classification in mandible. RPDs were more prevalant in Kennedy I and II patients ( $80.5 \%$ and $44.7 \%$, respectively), while FPDs were more prevalant in Kennedy III patients (69.4\%).

Table 3: Distribution of treatment type according to Kennedy classification in mandible

\begin{tabular}{|l|c|c|c|c|c|c|c|c|}
\hline \multicolumn{7}{|c|}{ Age groups } \\
\hline & \multicolumn{7}{|c|}{ Gaxilla } & \multicolumn{2}{c|}{ Gender } \\
\hline & $20-29$ & $30-39$ & $40-49$ & $50-59$ & $60-69$ & $70+$ & Male & Female \\
\hline KI & 0 & $1(4 \%)$ & $2(8 \%)$ & $6(24 \%)$ & $14(56 \%)$ & $2(8 \%)$ & $8(32 \%)$ & $17(68 \%)$ \\
\hline KII & 0 & $1(2.6 \%)$ & $9(23 \%)$ & $10(25.6 \%)$ & $12(30.8 \%)$ & $7(18 \%)$ & $14(36 \%)$ & $25(64 \%)$ \\
\hline KIII & $11(6.3 \%)$ & $42(24 \%)$ & $44(25.2 \%)$ & $49(28 \%)$ & $23(13.2 \%)$ & $6(3.3 \%)$ & $76(43.5 \%)$ & $99(56.5 \%)$ \\
\hline KIV & $1(14.3 \%)$ & 0 & $3(42.9 \%)$ & $2(28.5 \%)$ & 0 & $1(14.3 \%)$ & $3(42.9 \%)$ & $4(57.1 \%)$ \\
\hline p & & & & & & & \\
\hline
\end{tabular}

Only 1 overdenture was constructed in a Kennedy I class in mandible.

According to Table 4, a significant difference was found between the age groups and Kennedy classifications in maxilla $(p<0.01)$.

Table 4: The effect of age and gender on Kennedy classification in maxilla

\begin{tabular}{|l|c|c|c|c|c|c|c|c|}
\hline \multicolumn{7}{|c|}{ Age groups } \\
\hline & \multicolumn{7}{|c|}{ Gaxilla } & \multicolumn{2}{c|}{ Gender } \\
\hline & $20-29$ & $30-39$ & $40-49$ & $50-59$ & $60-69$ & $70+$ & Male & Female \\
\hline KI & 0 & $1(4 \%)$ & $2(8 \%)$ & $6(24 \%)$ & $14(56 \%)$ & $2(8 \%)$ & $8(32 \%)$ & $17(68 \%)$ \\
\hline KII & 0 & $1(2.6 \%)$ & $9(23 \%)$ & $10(25.6 \%)$ & $12(30.8 \%)$ & $7(18 \%)$ & $14(36 \%)$ & $25(64 \%)$ \\
\hline KIII & $11(6.3 \%)$ & $42(24 \%)$ & $44(25.2 \%)$ & $49(28 \%)$ & $23(13.2 \%)$ & $6(3.3 \%)$ & $76(43.5 \%)$ & $99(56.5 \%)$ \\
\hline KIV & $1(14.3 \%)$ & 0 & $3(42.9 \%)$ & $2(28.5 \%)$ & 0 & $1(14.3 \%)$ & $3(42.9 \%)$ & $4(57.1 \%)$ \\
\hline p & & & & & & & \\
\hline
\end{tabular}

Kennedy I was the most prevalent type in 60-69 age groups (56\%). However, there was no significant difference between the gender and Kennedy classifications. There was a significant difference between the age groups, gender and Kennedy classifications in mandible (Table 5). Females had more Kennedy II jaws than males $(p<0.05)$.

Table 5: The effect of age and gender on Kennedy classification in mandible

\begin{tabular}{|c|c|c|c|c|c|c|c|c|}
\hline \multicolumn{9}{|c|}{ Mandible } \\
\hline & \multicolumn{6}{|c|}{ Age groups } & \multicolumn{2}{|c|}{ Gender } \\
\hline & $20-29$ & $30-39$ & $40-49$ & $50-59$ & $60-69$ & $70+$ & Male & Female \\
\hline KI & 0 & $2(3 \%)$ & $9(13.7 \%)$ & $22(33.3 \%)$ & $23(34.8 \%)$ & $10(15.2 \%)$ & $29(44 \%)$ & $37(56 \%)$ \\
\hline KII & $2(3.5 \%)$ & $7(12.5 \%)$ & $11(19.7 \%)$ & $13(23.2 \%)$ & $12(21.4 \%)$ & $11(19.7 \%)$ & $15(27 \%)$ & $41(73 \%)$ \\
\hline KIII & $8(5 \%)$ & $41(26.2 \%)$ & $51(32.6 \%)$ & $34(21.6 \%)$ & $17(10.8 \%)$ & $6(3.8 \%)$ & $69(44 \%)$ & $88(56 \%)$ \\
\hline KIV & 0 & 0 & 0 & 0 & $1(50 \%)$ & $1(50 \%)$ & $2(100 \%)$ & 0 \\
\hline $\mathrm{p}$ & \multicolumn{6}{|c|}{$0.001^{* *}$} & \multicolumn{2}{|c|}{$0.021^{*}$} \\
\hline
\end{tabular}

\section{DISCUSSION}

The aim of this epidemiological study was to evalute the types of partial edentulism and to determine the prosthetic rehabilitation of each type in a group of patients in Istanbul between 2008 and 2010. Kennedy classification which is the most widely used system was preferred to fulfill this purpose. ${ }^{14}$ This is a logical method of classification that permits the immediate visualization of the partially edentuluos arches. ${ }^{8}$ In this study, the classifications were recorded after the other dental treatments such as periodontal, endodontic and surgical treatments were completed, just before the prosthetic stage. Patients whose prosthetic treatments had been finished or who had no any prosthetic treatment were recorded. According to results, the most frequent type of partial edentulism was Kennedy III, and the least prevalent type was Kennedy IV in both the maxilla and the mandible. This observation can be explained by lower extraction rate in anterior teeth probably because they are relatively resistant to caries, more accessible for complicated endodontic and restorative treatments, and their extraction may be delayed due to esthetic reasons. ${ }^{15}$ This was also true for the studies from other countries such as Jordan, Nigeria, Saudi Arabia and Kazakhstan., ${ }^{3,11-13}$ However, this result was in contrast to studies conducted in Turkey, ${ }^{9}$ Greece $^{7}$ and USA, ${ }^{6}$ which reported that Kennedy I and II were the most prevalent type of edentulism. The prevalence of partial edentulism varies in different countries or regions, related to differences in socioeconomic status, educational levels, and patient perspectives toward dental health. ${ }^{3}$ In the present study, it can be clearly observed that RPDs were more common than the other treatment options in Kennedy I and II jaws for both maxilla and mandible. Distal-extension RPD (Kennedy I and II) has the advantage of being less expensive, less complicated and reversible. ${ }^{5}$ However, they may be associated with several problems related to poor stability, poor retention, esthetics, masticatory efficiency, low patient satisfaction and low oral comfort. ${ }^{16-20}$ The main problems of RPDs are caries, resorption of the residual alveolar ridge and inflammation of the underlying mucosa, probably because of its dual-support system with different resilience. ${ }^{21}$ Dental implants may be an alternative treatment to RPDs. ${ }^{22-24}$ In this study, dental implants were less common treatment option for Kennedy I and II in both maxilla and mandible (15-20\% and 25$26 \%$, respectively). This result is in accordance with the study preformed in Kazakhstan, in which dental implants were the least common treatment choice. ${ }^{3}$ The reasons for such a result may be the high cost, long treatment period, insufficient anatomical conditions and necessity of additional surgical procedures, patients' attitudes toward their dental health, or dentists' preferences. In addition, implant therapy is not financially supported by dental in- 
surance in Turkey. ${ }^{25}$ These factors may hinder patients to select implant treatment.

FPDs were the most (57\%) and RPDs were the least common treatment option for Kennedy IV jaws in maxilla (14.5\%). This result is in contrast to a study preformed in Kazakhstan, in which the RPDs were the most common treatment choice $(75 \%) .{ }^{3}$ Patients in this study may have less tooth missing, enable to restore edentulous spaces with FPDs. In addition, FPDs were the most common treatment option for Kennedy III jaws in maxilla (76\%), and this result is in accordance with the same study, in which the FPDs were the most common treatment choice (87.5\%). ${ }^{3}$ FPDs supported by natural teeth provide stable occlusal conditions, high retention and better patient comfort when compared with RPDs. ${ }^{5}$

In cases with only one or more molar teeth missing in Kennedy II cases, treatment with small distal extension cantilevered FPDs may be an alternative reconstruction method. This treatment is relatively simple, inexpensive, not time-consuming and easy to adapt especially for the elderly patients. ${ }^{26}$ In this study, $12-15 \%$ of the patients had FPDs on their Kennedy II jaws. On the other hand, 7-16\% of the patients with Kennedy II jaws had no treatment. These patients may be young and they may consider to have implants in the near future, or they may be old and prefer to live with a shortened dental arch. If the patients had Kennedy II jaws for a long while, elongated antagonist teeth may avoid restoring the edentulous spaces, and the patients may be reluctant to have complicated treatments including endodontics and/or crown lengthening procedures for the elongated teeth. The ratio of the Kennedy III patients with no treatment was between $9.7 \%$ and $12 \%$. The patients may have single tooth missing in posterior region, tilted molars or narrow spaces, imposing difficulties in constructing FPDs or implants, which may explain the choice of no treatment. Only $3.4 \%$ and $3.8 \%$ of the Kennedy III cases had RPDs, probably because of the improper periodontal situations of the abutment teeth for FPDs. This result is similar with the Charyeva's study. ${ }^{3}$

There was one patient (1.5\%) who had overdenture on his Kennedy I mandible with only 2 canines. In the partially edentulous patients with few and unfavourably distributed remaining teeth, complete overdentures are indicated to improve retention of the dentures and satisfaction of the patients. ${ }^{5}$

According to results, it was clearly observed that Kennedy I and II types were significantly more prevalent in patients over the age of 60 . Douglass and Watson stated that the needs for rehabilitation of partially edentulism will increase by $15 \%$ from 2005 to 2020 in the United States. ${ }^{27}$ Although there are no available data on the predicted rates of partial edentulism in Turkey to the authors' knowledge, an extended lifetime and a large increase in the number of elderly individuals are expected in the future. Therefore, there will be a large number of patients with partially edentulism, and rehabilitation is still necessary to meet the prosthetic needs of the society. ${ }^{28}$

The limitations of the present study is that only one dental hospital is included in the study which is conducted on a group of patients, and definitely reflects the partial edentulism classification and treatment choices of only a limited group. Future studies performed in different regions of the country with higher sample size that focus on the treatment options of partial edentulism will be supportive in delivering the best information to dental health planners.

\section{CONCLUSIONS}

The choice of prosthetic treatment modality is mainly determined by the patient's expectations, needs, social aspects, economical consequences and educational level, as well as the general health status, oral functional benefits, esthetic, prognosis of the remaining teeth, risks with regard to periodontal diseases, caries progression and patient motivation to maintain oral hygiene. The clinician's knowledge related to art and science in prosthodontics, judgement abilities and appropriate insight are also curical factors in order to respond patients' demands.

\section{REFERENCES}

1. Hessari $\mathrm{H}$, Vehkalahti MM, Eghbal MJ, Murtomaa $\mathrm{H}$. Tooth loss and prosthodontic rehabilitation among 35- to 44-year-old Iranians. J Oral Rehabil 2008; 35: 245-251.

2. Zitzmann NU, Hagmann E, Weiger R. What is the prevalence of various types of prosthetic dental restorations in Europe? Clin Oral Implants Res 2007; 18 Suppl 3: 20-33.

3. Charyeva OO, Altynbekov KD, Nysanova BZ. Kennedy classification and treatment options: a study of partially edentulous patients being treated in a specialized prosthetic clinic. J Prosthodont 2012; 21: 177-180.

4. Dhingra K. Oral rehabilitation considerations for partially edentulous periodontal patients. J Prosthodont 2012; 21: 494-513.

5. Budtz-Jörgensen E. Restoration of the partially edentulous mouth--a comparison of overdentures, removable partial dentures, fixed partial dentures and implant treatment. J Dent 1996; 24: 237-244.

6. Curtis DA, Curtis TA, Wagnild GW, Finzen FC. Incidence of various classes of removable partial dentures. J Prosthet Dent 1992; 67: 664-667.

7. Niarchou AP, Ntala PC, Karamanoli EP, Polyzois GL, Frangou MJ. Partial edentulism and removable partial denture design in a dental school population: a survey in Greece. Gerodontology 2011; 28: 177-183.

8. Henderson D, McGivney GP, Castleberry DJ. McCrack- 
en's removable partial prosthodontics. 7th ed. CV Mosby. St. Louis, Toronto, Princeton 1985, pp: 21-126.

9. Keyf F. Frequency of the Various Classes of Removable Partial Dentures and Selection of Major Connectors and Direct/Indirect Retainers. Turk J Med Sci 2001; 31: 445449.

10. The Glossary of Prosthodontic Terms. 7th ed. CV Mosby. 2005; 94, pp: 47.

11. AL-Dwairi ZN. Partial edentulism and removable denture construction: a frequency study in Jordanians. Eur $\mathrm{J}$ Prosthodont Restor Dent 2006; 14: 13-17.

12. Ehikhamenor EE, Oboro HO, Onuora Ol, et al. Types of removable prostheses requested by patients who were presented to the University of Benin Teaching Hospital Dental Clinic. J Dent Oral Hyg 2010; 2: 15-18.

13. Sadig WM, Idowu AT. Removable partial denture design: a study of a selected population in Saudi Arabia. J Contemp Dent Pract 2002; 15: 40-53.

14. Miller EL. Systems for classifying partially dentulous arches. J Prosthet Dent 1970; 24: 25-40.

15. McCaul LK, Jenkins WM, Kay EJ. The reasons for the extraction of various tooth types in Scotland: a 15-year follow up. J Dent 2001; 29: 401-407.

16. Brudvik JS. Implants and removable partial dentures. In: Brudvick JS, ed. Advanced removable partial dentures. Chicago: Quitnessence Publishing Co; 1999; p: 153-159. 17. Jepson NJ, Thomason JM, Steele JG. The influence of denture design on patient acceptance of partial dentures. Br Dent J 1995; 178: 296-300.

18. Vermeulen AH, Keltjens HM, van't Hof MA, Kayser AF. Ten-year evaluation of removable partial dentures: survival rates based on retreatment, not wearing and replacement. J Prosthet Dent 1996; 76: 267-272.

19. Wetherell JD, Smales RJ. Partial denture failures: a long-term clinical survey. J Dent 1980; 8: 333-340.

20. Wostmann B, Budtz-Jorgensen $E$, Jepson $N$, Mushimoto E, Palmqvist $S$, Sofou A et al. Indications for removable partial dentures: a literature review. Int J Prosthodont 2005; 18: 139-145.

21. de Freitas RF, de Carvalho Dias $K$, da Fonte Porto Carreiro A, Barbosa GA, Ferreira MA. Mandibular implant-supported removable partial denture with distal extension: a systematic review. J Oral Rehabil 2012; 39: 791-798.

22. Quirynen $M$, Naert I, van Steenberghe $D$, Dekeyser C, Callens A. Periodontal aspects of osseointegrated fixtures supporting a partial bridge. An up to 6-years retrospective study. J Clin Periodontol 1992; 19: 118-126.

23. Zarb GA, Schmitt A. The longitudinal clinical effectiveness of osseointegrated dental implants in posterior partially edentulous patients. Int J Prosthodont 1993; 6: 189-196.

24. Heydecke G, Boudrias $P$, Awad MA, De Albuquerque RF, Lund JP, Feine JS. Within-subject comparisons of maxillary fixed and removable implant prostheses: Patient satisfaction and choice of prosthesis. Clin Oral Implants Res 2003; 14: 125-130.

25. Ozkurt Z, Kazazoğlu E. Treatment modalities of single-tooth missing in a Turkish subpopulation: Implant, fixed partial denture or no restoration. J Dent Sci 2010; 5: 183-188.

26. Budtz-Jørgensen E, Isidor F, Karring T. Cantilevered fixed partial dentures in a geriatric population: preliminary report. J Prosthet Dent 1985; 54: 467-473.

27. Douglass CW, Watson AJ. Future needs for fixed and removable partial dentures in the United States. J Prosthet Dent 2002; 87: 9-14.

28. Dikbas I, Ozkurt Z, Kazazoglu E. Predoctoral prosthodontic curriculum on removable partial dentures: survey in Turkish dental faculties. J Dent Educ 2013; 77: 85-92. 
7tepeklinik 